ISSN 0258-7122

Bangladesh J. Agril. Res. 38(1): 127-136, March 2013

\title{
EFFECT OF IRRIGATION ON HARVESTING TIME AND YIELD IN MANGO (Mangifera indica L.)
}

\author{
BABUL C. SARKER ${ }^{1}$ AND M. A. RAHIM ${ }^{2}$
}

\begin{abstract}
An experiment was carried out at the BAU Germplasm Centre, Department of Horticulture, Bangladesh Agricultural University, Mymensingh to investigate the effect of irrigation on harvesting time, yield and quality attributes of mango cv. BARI Aam -3 (Amrapali) during the period from September 2005 to July 2006. There were seven treatments in the experiment viz., Irrigation at 15th October, Irrigation at 15 October and 15 November, Irrigation at 15th of each month starting from October and continued up to December, Irrigation at 15th of each month starting from October and continued up to January, Irrigation at 15th of each month starting from October and continued up to February, Irrigation at 15th of each month starting from October and continued up to March and Control (no irrigation). The plants those were irrigated twice on 15 October and 15 November exhibited the highest number of panicles per plant (137.33) compared to the lowest number of panicles per plant (9.00) in the treatment where irrigation was given at 15th of each month starting from October and continued up to March. Two irrigations at 15 October and 15 November produced the highest number of fruits per plant (61.67) and irrigation applied on 15th of each month starting from October and continued up to December produced the lowest number of (11.00) fruits. Maximum yield (12.50 kg/plant) was recorded from the plants which were irrigated twice on 15 October and 15 November as compared to minimum yield (2.15 kg/plant) in plants irrigated on 15th of each month starting from October and continued up to December. Irrigation applied on 15th of each month starting from October to March resulted in the longest shelf life ( 7.28 days) as compared to control (5.63 days).
\end{abstract}

Keywords: Irrigation, harvesting time, yield of mango.

\section{Introduction}

Mango (Mangifera indica L.) occupied a pre-eminent place amongst the fruit crops grown in Bangladesh. It grows in an area of 51.012 thousand hectares with an annual total production of 242.605 thousand metric tons having an average yield of 4.75 tons per hectare (BBS, 2005), which is very low as compared to those of other mango growing countries like India (8.95 t/ha) (Ghosh, 1998) and the Philippines (9.41 t/ha) (Espino and Javier, 1989). Irregular or erratic flowering, low fruit set as well as retention leading to low yield and fruits of poor

${ }^{1}$ Principal Scientific Officer, Pomology Division, Horticulture Research Centre, Bangladesh Agricultural Research Institute (BARI), Joydebpur, Gazipur, ${ }^{2}$ Professor, Department of Horticulture, Bangladesh Agricultural University (BAU), Mymensingh, Bangladesh. 
quality are also the main problems in mango production. Irrigation is an important measure which can affect the flowering, harvesting, yield and quality of mango. Higher fruit retention, yield and quality of mango largely depend on irrigation, which is to be applied in appropriate time with adequate amount. In South Florida, from a survey, it indicates that irrigation is a critical management for tropical fruit production (i.e., avocado, lime, mango, carambola, lychee, longan, mamey sapote and papaya) (Li et al., 2000). It is believed that irrigation from the time of fruit-set till the monsoons tends to prevent fruit drop and helps the fruits to improve in size and quality (Singh, 1968). According to Hossain (1989) the need for irrigation of mango plant arises earlier during the drier part of year, from November to April, and lesser in summer (May to June) and the least in the rainy season and autumn (July-October). The plants of bearing stage should be irrigated only after fruit set and following a fortnight interval. Two irrigations ( $1^{\text {st }}$ March and 15 March) at Mango Research Station, Nawabganj resulted in higher fruit retention and per cent fruit retention as compared with control (Uddin and Amin, 1994). Irrigation at Himachal, India at $20 \%$ and $40 \%$ depletion of available soil moisture increased yield at $87 \%$ and $79 \%$ compared to no irrigation (Ranbir et al., 1998). A period of quiescence reinforced by low winter temperatures (mean $16^{\circ} \mathrm{C}$ ) is a prerequisite for floral induction in mango in the dry-tropic of Australia (Bally et al., 2000). Withholding irrigation significantly increased the number of terminals that flowered by $20.5 \%$. Tree yields were increased by $17 \%$ through withholding irrigation than irrigation throughout the year. Water stress delaying the development of vegetative buds, the growth of floral buds was stimulated by water stress. Low temperature promoted floral induction of mango, whereas water stress promoted growth of florally induced buds. Water stress advanced floral bud break by nearly 2 weeks in nearly $40 \%$ of buds (Nunez and Davenport, 1994). Little information is available on the effect of irrigation on panicle emergence, flowering and fruiting of mango in Bangladesh. With this view, it was considered desirable to undertake the present experiment in order to standardize the irrigation schedule for proper flowering, higher yield as well as quality in addition to extending availability period of fresh mango fruits.

\section{Materials and Method}

The experiment was carried out at the BAU Germplasm Centre, Department of Horticulture, Bangladesh Agricultural University, Mymensingh during the period from September 2005 to July 2006. Soil of the Germplasm Centre was sandy loam which belongs to the Old Brahmaputra Flood Plain Alluvial Tract (UNDP, 1988). The average annual rainfalls for 2005 and 2006 were $264.18 \mathrm{~cm}$ and $201.62 \mathrm{~cm}$, respectively. The cultivar BARI Aam -3 (Amrapali) was included in the study and the age of the plants was 8 years having plant spacing of $5 \mathrm{~m} \times 5 \mathrm{~m}$. The single factor experiment was laid out in a Randomized Complete Block Design (RCBD) with three replications. The treatments were; $\mathrm{I}_{1}$ : Irrigation at 15 th October, $\mathrm{I}_{2}$ : Irrigation at 15 th October and 15 November. $I_{3}$ : Irrigation at 15 th of each month 
starting from October and continued up to December, $\mathrm{I}_{4}$ : Irrigation at 15th of each month starting from October and continued up to January, $\mathrm{I}_{5}$ : Irrigation at 15th of each month starting from October and continued up to February, $\mathrm{I}_{6}$ : Irrigation at 15th of each month starting from October and continued up to March, $\mathrm{I}_{7}$ : Control (no irrigation). Irrigation following basin method was applied up to field capacity. Adequate care and management of the plants under the experiment was taken as per requirement. The plants were properly fertilized, and for controlling diseases, Bavistin @ 2 ml/L and for insects, Sumithion@ 2 ml/L, were applied once before flower opening and at pea stage of fruit. Data were recorded on length of terminal shoot, number of leaves per terminal shoot, leaf area, length of panicle, breadth of panicle, number of secondary branches per panicle, date of first panicle appearance, number of panicles emerged per plant at 10-day intervals starting from first appearance of panicle, fruit set per panicle, while number of fruits retained per panicle were recorded at 10-day intervals starting from pea stage upto harvest. Besides, data on date of harvest, number of fruits per plant, fruit weight, fruit length, fruit breadth, fruit thickness, yield, edible portion, stone: pulp ratio, peel: pulp ratio, TSS and shelf life were also recorded. The number of leaves of ten randomly selected terminal shoots at flowering stage was counted and the average was worked out. Leaf area was measured for all the 50 leaves taking 5 from each of ten above selected shoots by a leaf area meter and expressed in square centimeter. The length and breadth of panicle and number of secondary branches per panicle of 10 randomly tagged panicles covering the whole tree were recorded and the average was worked out. Ten panicles were randomly selected from each treatment. The initial number of fruits in each panicle and the fruits to be retained per panicle at 10 day intervals starting from pea stage up to harvest was counted and the average was worked out. After harvest, 10 randomly selected fruits from each plant were used for collecting fruit parameters. Total soluble solid (TSS) of 10 fully ripe fruits from each treatment was estimated by a hand refractometer and the average was worked out. The difference between the harvesting date and the date up to which the fruits remained edible was considered as shelf life. The recorded data on different parameters of the experiment was tabulated and analyzed following appropriate design of experiment (Gomez and Gomez, 1984). All the treatment means were separated using Least Significant Difference (LSD) test at 5\% level of significance.

\section{Results and Discussion}

\section{Effect of irrigation on leaf, shoot and panicle characters}

There were significant differences in terms of terminal shoot length, number of leaves per terminal shoot, leaf area, length and breadth of panicle and number of secondary branches per panicle as influenced by different irrigation treatments (Table 1). The longest terminal shoot was noted when plants received irrigation 
at 15th of each month starting from October and continued up to March (7.58 $\mathrm{cm})$, which was followed by the irrigation at 15th of each month starting from November and continued up to February $(7.04 \mathrm{~cm})$ and the minimum value $(5.80$ $\mathrm{cm}$ ) was recorded in control (no irrigation). The increase in terminal shoot length due to irrigation in this study may be attributed to the uptake of sufficient nutrient elements from the soil. The treatment irrigation at 15th of each month starting from October and continued up to March produced maximum number of leaves per terminal shoot (7.60) which was statistically at par to those of irrigation at 15th of each month starting from October and continued up to February (7.49) and irrigation at 15th of each month starting from October and continued up to January (7.25). The unirrigated control plants produced minimum (6.17) number of leaves. Irrigated plants exhibited favourable effect on leaf production in comparison with control. The reason may be the same as above. Plants receiving irrigation at 15th of each month starting from October and continued up to March resulted in maximum leaf area $\left(56.16 \mathrm{~cm}^{2}\right)$ followed by the irrigation at 15 th of each month starting from October and continued up to February $\left(51.96 \mathrm{~cm}^{2}\right)$, whereas the control plants resulted in the lowest leaf area $\left(40.02 \mathrm{~cm}^{2}\right)$. Higher supply of nutrients may also lead to increase leaf area in the irrigated treatments. The plants irrigated twice on 15 October and 15 November exhibited the highest panicle length and breadth $(25.55 \mathrm{~cm}$ and $19.53 \mathrm{~cm})$ which were statistically at par to those of the treatments irrigation only on 15 October $(25.05$ and $19.17 \mathrm{~cm}$ ) and 15 of each month starting from October and continued up to March (23.33 $\mathrm{cm}$ and $18.20 \mathrm{~cm}$ ). The plants in the control recorded the least panicle length and breadth $(21.30 \mathrm{~cm}$ and $17.15 \mathrm{~cm})$. Irrigation applied twice on 15 October and 15 November produced the maximum number of secondary branches per panicle (32.83), which was followed by irrigation only on 15 October (31.68). The unirrigated plants noted minimum secondary branches of 24.78 per panicle. Li et al. (2000) also indicated from a survey in south Florida that irrigation depends on time of year and crop growth stage and appearance which lend support to the present findings.

Table 1. Effect of irrigation on leaf, shoot and panicle characters of mango.

\begin{tabular}{c|c|c|c|c|c|c}
\hline Treatments & $\begin{array}{c}\text { Length of } \\
\text { terminal } \\
\text { shoot }(\mathrm{cm})\end{array}$ & $\begin{array}{c}\text { No. of } \\
\text { leaves/ } \\
\text { terminal } \\
\text { shoot }\end{array}$ & $\begin{array}{c}\text { Leaf } \\
\text { area } \\
\left(\mathrm{cm}^{2}\right)\end{array}$ & $\begin{array}{c}\text { Length of } \\
\text { panicle } \\
(\mathrm{cm})\end{array}$ & $\begin{array}{c}\text { Breadth of } \\
\text { panicle } \\
(\mathrm{cm})\end{array}$ & $\begin{array}{c}\text { No. of } \\
\text { secondary } \\
\text { branches/ } \\
\text { panicle }\end{array}$ \\
\hline $\mathrm{I}_{1}$ & 6.20 & 6.39 & 43.06 & 25.05 & 19.17 & 31.68 \\
$\mathrm{I}_{2}$ & 6.24 & 6.19 & 48.66 & 25.55 & 19.53 & 32.83 \\
$\mathrm{I}_{3}$ & 6.33 & 6.37 & 42.42 & 22.28 & 17.58 & 26.30 \\
$\mathrm{I}_{4}$ & 6.50 & 7.25 & 44.78 & 21.55 & 17.35 & 26.06 \\
$\mathrm{I}_{5}$ & 7.04 & 7.49 & 51.96 & 22.83 & 17.85 & 27.83 \\
$\mathrm{I}_{6}$ & 7.58 & 7.60 & 56.16 & 23.33 & 18.20 & 27.90 \\
$\mathrm{I}_{7}$ & 5.80 & 6.17 & 40.02 & 21.30 & 17.15 & 24.78 \\
\hline $\mathrm{CV}(\%)$ & 4.48 & 6.92 & 6.79 & 4.55 & 4.84 & 4.27 \\
$\mathrm{LSD}(0.05)$ & 0.55 & 0.83 & 5.64 & 1.98 & 1.56 & 2.27 \\
\hline
\end{tabular}




\section{Effect of irrigation on panicle appearance and number of panicles per plant}

Date of first panicle appearance among different treatments varied from 25 January 2006 to 04 February 2006 (Table 2). The plants irrigated twice on 15 October and 15 November exhibited the earliest emergence (25.01.06) as compared to the delayed appearance in most of the treatments except irrigation at 15 October, 15 October and 15 November and the control. Number of panicles per plant at all dates of data recorded was found to be significant as influenced by different irrigation treatments (Table 2). From starting date upto final data record, the plants irrigated twice on 15 October and 15 November always registered the highest number of panicles per plant. Finally, on 06.03.06, maximum number of panicles per plant (137.33) was recorded from the treatment irrigation twice on 15 October and 15 November. Minimum number of panicles per plant at all dates was noticed from irrigation at 15th of each month starting from October and continued up to March. The late and fewer emergences were happened may be due to less storage of food due to excessive vegetative growth and dearth of sufficient dormant period. Bally et al., (2000) claimed that withholding irrigation from maturation of the first vegetative flush following harvest until $90 \%$ of buds were anatomically floral and irrigation withheld from maturation of the first vegetative flush following harvest until $70 \%$ of inflorescences had emerged significantly increased the number of terminals that flowered by $20.5 \%$ and yields were increased by $17 \%$ through withholding irrigation.

Table 2. Effect of irrigation on emergence and number of panicles per plant.

\begin{tabular}{c|c|c|c|c|c}
\hline \multirow{2}{*}{ Treatments } & $\begin{array}{c}\text { Date of first } \\
\text { appearance of } \\
\text { panicle }\end{array}$ & \multicolumn{4}{|c}{ Number of panicles/plant at } \\
\cline { 3 - 6 } & 28.01 .06 & 45.02 .06 & 14.02 .06 & 24.02 .06 & 06.03 .06 \\
\hline$I_{1}$ & 25.01 .06 & 77.67 & 83.67 & 86.67 & 95.33 \\
$I_{2}$ & 04.02 .06 & 5.33 & 11.67 & 12.67 & 15.67 \\
$I_{3}$ & 04.02 .06 & 3.33 & 9.67 & 11.00 & 14.00 \\
$I_{4}$ & 04.02 .06 & 1.67 & 6.67 & 8.33 & 12.33 \\
$I_{5}$ & 04.02 .06 & 1.33 & 2.66 & 5.33 & 9.00 \\
$I_{6}$ & 28.01 .06 & 43.22 & 57.33 & 63.67 & 68.67 \\
$I_{7}$ & - & 6.69 & 8.78 & 9.18 & 4.91 \\
CV (\%) & - & 3.02 & 4.59 & 7.45 & 4.39 \\
\hline LSD (0.05) & - & & & &
\end{tabular}

\section{Effect of irrigation on fruit set and fruit retention per panicle}

Irrigation treatments had marked influences on fruit set per panicle (Table 3). Plants irrigated at $15^{\text {th }}$ of each month starting from October and continued up to March showed the maximum fruit set per panicle (7.25), which was followed by irrigation at 15th of each month starting from October and continued up to February (6.55) and irrigation at 15th of each month starting from October and 
continued up to January (6.13), whereas the control plants exhibited the lowest fruit set per panicle (3.58). The number of fruits borne per panicle due to the irrigation treatments varied significantly at all dates of data recorded (Table 3). The plants which were irrigated at 15th of each month starting from October to March always manifested maximum number of fruits per panicle up to harvest, as compared to the minimum number of fruits per panicle in unirrigated plants. At harvest, the treatment $\mathrm{I}_{6}$ recorded 1.58 numbers of fruits per panicle and a minimum value with 0.55 in unirrigated plants. With the increase of irrigation frequencies, fruit set as well as fruit retention per panicle were also increased and this was may be due to the proper availability of plant nutrients for longer time. Uddin and Amin (1994) also reported that two irrigations (1 March and 15 March) on mango var. Aswina resulted in higher fruit retention as compared to that of control.

\section{Effect of irrigation on harvest date, number of fruits per plant, fruit characters, yield and quality of mango}

Date of harvest ranged from 24 June 2006 to 01 July 2006 (Table 4). The treatments irrigation once at 15 October, twice at 15 October and 15 November and the control plants had earlier and same date of harvest (24.06.06). The fruits from rest of the treatments were harvested lately on 01 July 2006. The control and the plants irrigated upto November had earlier harvest each on 24.06.06 as compared to delayed harvest in rest of the treatments each on 01.07.06. Significant variations in relation to number of fruits per plant, weight, length, breadth and thickness of fruit, stone: pulp ratio, peel: pulp ratio, yield, TSS and shelf life were observed due to irrigation treatments except edible portion where the treatments did not vary significantly (Table 4). Irrigation twice on 15 October and 15 November produced the highest number of fruits per plant (61.67). Irrigation applied at 15th of each month starting from October and continued up to December $\left(\mathrm{I}_{3}\right)$ produced the lowest $(11.00)$ fruits which was statistically at par to those of $\mathrm{I}_{4}$ (12.67), $\mathrm{I}_{5}$ (14.33) and $\mathrm{I}_{6}$ (15.00). Irrigation at 15th of each month starting from October and continued up to March $\left(\mathrm{I}_{6}\right)$ gained maximum mean fruit weight (266.67 g) closely followed by the irrigation provided on 15 of each month starting from October to February which recorded $253.67 \mathrm{~g}$ as compared to the least fruit weight of $166.00 \mathrm{~g}$ in the unirrigated control. The treatment irrigation applied on 15th of each month starting from October and continued up to March manifested the longest and widest fruit $(10.62 \mathrm{~cm} 7.20 \mathrm{~cm})$, which was followed by the irrigation applied on 15 of each month starting from October to February $(10.11 \mathrm{~cm}$ and $7.04 \mathrm{~cm})$. The unirrigated control plants exhibited the shortest and narrowest fruit $(8.34 \mathrm{~cm} 6.07 \mathrm{~cm})$. Plants irrigated on 15th of each month starting from October and continued up to March produced the thickest fruit $(6.40 \mathrm{~cm})$ as against the thinnest fruit (5.68) in unirrigated control plants. The lowest but same stone: pulp ratio $(0.28)$ was recorded from the plants 
Table 3. Effect of irrigation on fruit set and number of fruits retained per panicle.

\begin{tabular}{|c|c|c|c|c|c|c|c|c|c|c|c|}
\hline \multirow[b]{2}{*}{ Treatments } & \multirow{2}{*}{$\begin{array}{c}\text { Fruit set } \\
\text { per } \\
\text { panicle }\end{array}$} & \multicolumn{10}{|c|}{ Number of fruits retained per panicle at } \\
\hline & & $\begin{array}{c}22.03 . \\
06\end{array}$ & $\begin{array}{c}01.04 . \\
06 \\
\end{array}$ & $\begin{array}{c}11.04 . \\
06\end{array}$ & $\begin{array}{c}21.04 \\
06\end{array}$ & $\begin{array}{c}01.05 \\
06\end{array}$ & $\begin{array}{c}11.05 . \\
06\end{array}$ & $\begin{array}{c}21.05 . \\
06\end{array}$ & $\begin{array}{c}31.06 . \\
06\end{array}$ & $\begin{array}{c}10.06 . \\
06\end{array}$ & Harvest \\
\hline $\mathrm{I}_{1}$ & 4.50 & 1.50 & 1.00 & 1.00 & 1.00 & 0.92 & 0.67 & 0.67 & 0.58 & 0.58 & 0.58 \\
\hline $\mathrm{I}_{2}$ & 5.13 & 2.17 & 1.00 & 1.00 & 1.00 & 1.00 & 0.67 & 0.67 & 0.67 & 0.67 & 0.58 \\
\hline $\mathrm{I}_{3}$ & 5.67 & 4.00 & 2.29 & 1.61 & 1.00 & 1.00 & 1.00 & 1.00 & 1.00 & 0.67 & 0.67 \\
\hline $\mathrm{I}_{4}$ & 6.13 & 4.17 & 3.08 & 1.89 & 1.39 & 1.39 & 1.17 & 1.08 & 1.00 & 0.93 & 0.93 \\
\hline $\mathrm{I}_{5}$ & 6.55 & 4.17 & 3.18 & 2.25 & 1.67 & 1.67 & 1.22 & 1.11 & 1.11 & 1.11 & 1.11 \\
\hline $\mathrm{I}_{6}$ & 7.25 & 4.33 & 3.67 & 3.00 & 1.82 & 1.79 & 1.58 & 1.58 & 1.58 & 1.58 & 1.58 \\
\hline $\mathrm{I}_{7}$ & 3.58 & 1.50 & 1.00 & 1.00 & 1.00 & 0.75 & 0.58 & 0.58 & 0.55 & 0.55 & 0.55 \\
\hline CV (\%) & 5.37 & 8.43 & 8.94 & 9.17 & 9.77 & 8.78 & 9.86 & 9.13 & 9.72 & 9.60 & 9.26 \\
\hline LSD (0.05) & 0.53 & 0.47 & 0.35 & 0.27 & 0.22 & 0.19 & 0.17 & 0.16 & 0.16 & 0.15 & 0.14 \\
\hline
\end{tabular}

Table 4. Effect of irrigation on number of fruits per plant, fruit characters and quality attributes of mango.

\begin{tabular}{|c|c|c|c|c|c|c|c|c|c|c|c|}
\hline \multirow[b]{2}{*}{$\begin{array}{l}\text { Treat- } \\
\text { ments }\end{array}$} & \multirow[b]{2}{*}{$\begin{array}{l}\text { Date of } \\
\text { harvest }\end{array}$} & \multirow[b]{2}{*}{$\begin{array}{l}\text { Number } \\
\text { of fruits } \\
\text { per plant }\end{array}$} & \multicolumn{4}{|c|}{ Fruit } & \multirow[b]{2}{*}{$\begin{array}{c}\text { Edible } \\
\text { portion } \\
(\%)\end{array}$} & \multirow[b]{2}{*}{$\begin{array}{l}\text { Stone } \\
\text { :pulp } \\
\text { ratio }\end{array}$} & \multirow[b]{2}{*}{$\begin{array}{l}\text { Peel } \\
\text { :pulp } \\
\text { ratio }\end{array}$} & \multirow[b]{2}{*}{$\begin{array}{l}\text { TSS } \\
\text { (\%) }\end{array}$} & \multirow[b]{2}{*}{$\begin{array}{c}\text { Shelf } \\
\text { life } \\
\text { (days) }\end{array}$} \\
\hline & & & $\begin{array}{l}\text { Weight } \\
\text { (g) }\end{array}$ & $\begin{array}{l}\text { Length } \\
\text { (cm) }\end{array}$ & $\begin{array}{l}\text { Breadth } \\
\text { (cm) }\end{array}$ & $\begin{array}{l}\text { Thick- } \\
\text { ness } \\
(\mathrm{cm})\end{array}$ & & & & & \\
\hline $\mathrm{I}_{1}$ & 24.06 .06 & 39.00 & 182.00 & 9.25 & 6.48 & 5.70 & 64.92 & 0.30 & 0.26 & 22.83 & 6.60 \\
\hline $\mathrm{I}_{2}$ & 24.06 .06 & 61.67 & 178.33 & 8.87 & 6.60 & 5.69 & 64.65 & 0.30 & 0.26 & 22.54 & 6.57 \\
\hline $\mathrm{I}_{3}$ & 01.07.06 & 11.00 & 190.33 & 9.12 & 6.64 & 6.23 & 65.22 & 0.30 & 0.25 & 23.50 & 6.67 \\
\hline $\mathrm{I}_{4}$ & 01.07.06 & 12.67 & 187.33 & 9.28 & 6.59 & 5.82 & 64.95 & 0.29 & 0.26 & 24.97 & 7.00 \\
\hline $\mathrm{I}_{5}$ & 01.07.06 & 14.33 & 253.67 & 10.11 & 7.04 & 6.13 & 65.60 & 0.28 & 0.25 & 25.33 & 7.17 \\
\hline $\mathrm{I}_{6}$ & 01.07.06 & 15.00 & 266.67 & 10.62 & 7.20 & 6.40 & 65.92 & 0.28 & 0.24 & 25.68 & 7.28 \\
\hline $\mathrm{I}_{7}$ & 24.06 .06 & 31.33 & 166.00 & 8.34 & 6.07 & 5.68 & 64.29 & 0.31 & 0.27 & 21.50 & 5.63 \\
\hline CV (\%) & - & 6.79 & 5.52 & 5.09 & 5.36 & 4.06 & 5.72 & 2.67 & 3.85 & 5.20 & 6.09 \\
\hline Lsd (0.05) & - & 3.19 & 20.00 & 0.85 & 0.64 & 0.43 & - & 0.01 & 0.01 & 2.20 & 0.73 \\
\hline
\end{tabular}




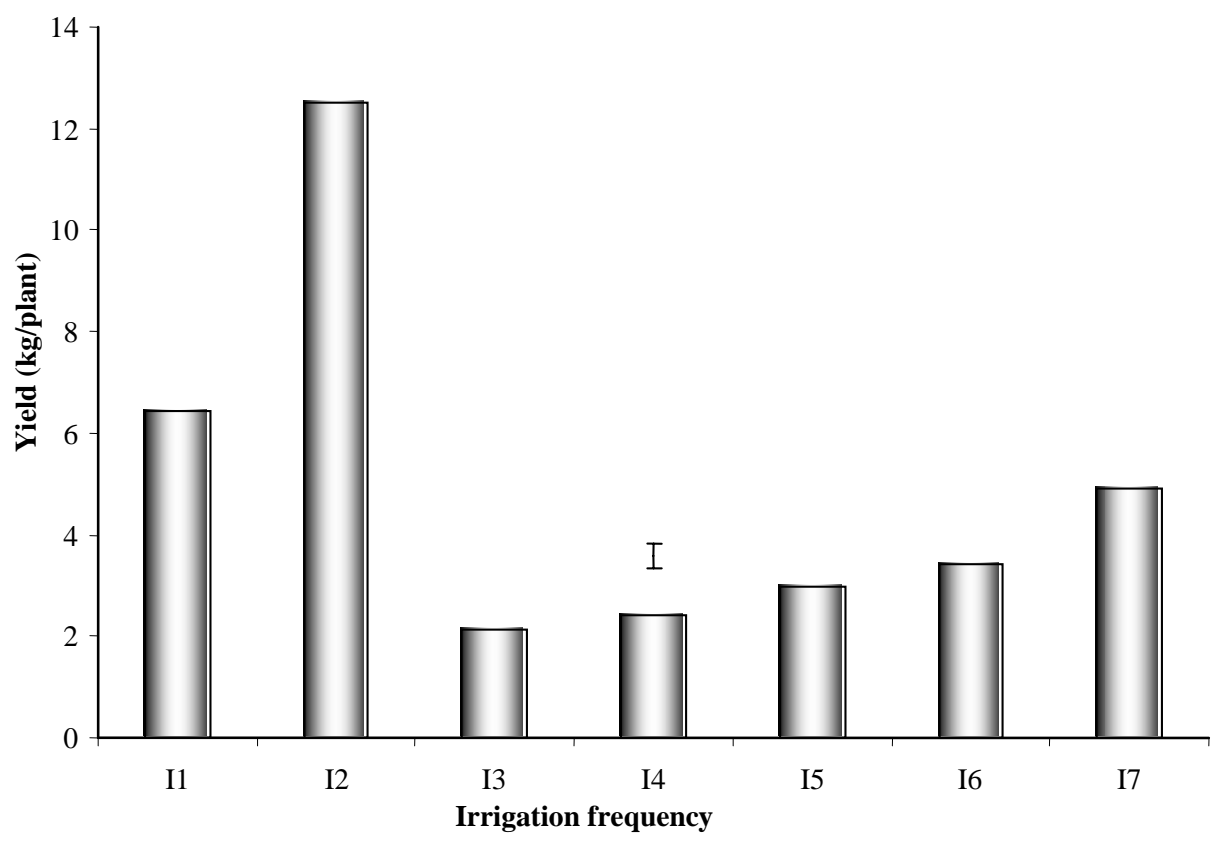

Fig. 1. Effect of irrigation on the yield per plant of mango. (Vertical bar represents LSD at $5 \%$ level.).

irrigated on 15 of each month starting from October to February and on 15 of each month starting from October to March compared to the highest stone pulp ratio (0.31) from unirrigated control plants. Minimum (0.24) peel: pulp ratio was obtained from the plants irrigated on 15 of each month starting from October to March and maximum ratio from the control (0.27). The highest yield (12.50 $\mathrm{kg} /$ plant) was recorded in plants which were irrigated twice on 15 October and 15 November. The lowest yield (2.15 kg/plant) was observed in case of plants irrigated at 15th of each month starting from October and continued up to December which was statistically identical to those of Irrigation at 15th of each month from October to January (2.40 kg/plant), irrigation at 15th of each month starting from October to February (2.97 kg/plant) and irrigation at 15th of each month from October to March (3.43 kg/plant). Withholding irrigation from maturation of the first vegetative flush following harvest until $90 \%$ of buds were anatomically floral and irrigation withheld from maturation of the first vegetative flush following harvest until $70 \%$ of inflorescences had emerged significantly increased the tree yields by $17 \%$ through withholding irrigation in two of three years (Bally et al., 2000). The higher number of panicles led higher fruits. The higher fruit yield from the treatment irrigation twice on 15 October and 15 November in terms of weight per plant could be attributed to the higher number of fruits despite little lower individual fruit weight. The highest yield obtained from the current investigation when irrigation continued up to 15 November 
corroborates the findings of Singh (1968) who opines that one irrigation with nitrogenous manures in September, another in the later half of October and a third with manure in November, would be desirable. This procedure may help the tree to break the periodicity in bearing by putting forth sufficient vegetative growth at a proper time. The highest TSS content (25.68\%) was noted in irrigation at 15th of each month starting from October and continued up to March, followed by irrigation at 15th of each month starting from October to February (25.33\%) and irrigation at 15th of each month starting from October and continued up to January (24.97\%), while fruits with the lowest TSS content of $21.50 \%$ was obtained from the control plants. The control plants showed the minimum shelf life (5.63 days) as compared to maximum value in the treatment irrigation applied on 15 of each month starting from October to March (7.28 days) which was statistically identical to those of $\mathrm{I}_{5}$ (7.17 days), $\mathrm{I}_{4}$ (7.00 days), $\mathrm{I}_{3}$, (6.67 days), $\mathrm{I}_{1}$ (6.60 days) and $\mathrm{I}_{2}$ (6.57 days). The size and quality of mango fruits is believed to be influenced by irrigation at appropriate time (Singh, 1968).

\section{Conclusion}

From the results, it reveals that irrigation on 15 October and 15 November may be recommended for better flowering, higher yield, and quality. It also reveals that when irrigation continues beyond November stating from October, once in a month, only a few panicles emerge and the yield becomes very low.

\section{References}

Bally, I. S. E., M. Harries, A. W. Whiley, S. Subhadrabandhu and A. Pichakum. 2000. Effect of water stress on flowering and yield of 'Kensington Pride' mango (Mangifera indica L.). Acta Hort. 509: 277-281.

BBS. 2005. Yearbook of Agricultural Statistics of Bangladesh 2004. Bangladesh Bureau of Statistics, Statistics Division, Planning Division, Ministry of Planning. Government of the Peoples' Republic of Bangladesh. P. 90.

Espino, R. R. C. and F. B. Javier. 1989. Present status of the mango industry in Philippines. Acta Hort. 231(1): 57-67.

Ghosh, S. P. 1998. Fruit weather of India. In: Tropical Fruits in Asia. Eds. R. K. Arora and V. R Rao. IPGR, India. Pp.3-5.

Gomez, K. A. and A. A. Gomez. 1984. Statistical Procedures for Agricultural Research. John Wiley and Sons, New York. Pp. 680.

Hossain A. K. M. A. 1989. Manual on Mango Cultivation in Bangladesh. Division of Horticulture, Bangladesh Agricultural Research Institute, Joydebpur, Gazipur, Pp. 40 $\& 82$.

Li, Yungong, B. Boman and C. Balerdi. 2000. Irrigation management survey for tropical fruit crops in south Florida. Proc. Fla. State Hort. Soc. 113: 40-42.

Nunez. E. R. and T. L. Davenport. 1994. Flowering of mango trees in containers as influenced by seasonal temperature and water stress. Scientia Hort. 58(1-2): 57-66. 
Ranbir, S., J. S. Chandel and A. R. Bhandari. 1998. Effect of soil-moisture regime on plant growth, fruiting, fruit quality and nutrient uptake of mango (Mangifera indica). Indian J. Agric. Sci. 68: (3) 135-138.

Singh, L. B. 1968. The mango Botany, Cultivation and Utilization. The mango Leonard Hill Ltd., London. P. 230.

Uddin M. Z. and M. A. Amin. 1994. Effect of irrigation on the yield and quality of mango Var. Aswina. A Research on Mango Improvement, RHRS, BARI, Nawabganj. P. 56.

UNDP. 1988. Land Resource Appraisal of Bangladesh for Agricultural Development Report 2: Agroecological Regions of Bangladesh. FAO, Rome. P. 577. 